\title{
The Ecological Outcome of Climate Change in Lake Kinneret-Thermal Pollution
}

\author{
Moshe Gophen \\ Migal, Scientific Research Institute, Kiryat Shmone, Israel \\ Email: Gophen@Migal.org.il
}

How to cite this paper: Gophen, M. (2019) The Ecological Outcome of Climate Change in Lake Kinneret-Thermal Pollution. Open Journal of Modern Hydrology, 9, 89-102. https://doi.org/10.4236/ojmh.2019.93005

Received: June 4, 2019

Accepted: July 13, 2019

Published: July 16, 2019

Copyright (C 2019 by author(s) and Scientific Research Publishing Inc. This work is licensed under the Creative Commons Attribution International License (CC BY 4.0).

http://creativecommons.org/licenses/by/4.0/

\begin{abstract}
Water quality deterioration as a result of pollution comprised of several aspects, among others: nutrient input loads, fishery management, hydrological budget, toxicity, watershed deforestation, soil exposure, and exotic invaders. Thermal pollution is mostly considered as the impact of power or nuclear Station effluent or the effect of exceptional thermal abrupt shock. The long-term influence of global warming consideration is not extensively studied. The long-term (1969-2001) effect of climate change (warming and precipitation decline) on the Lake Kinneret ecosystem is presented. Water and air Temperature, Heat Capacity and Thermal conductivity of water combined with reduced precipitation accompanied by lake water level decline are analyzed. It was found that the temperature of surface water increased with WL decline and decreased in deep layers during high WL. Future management design is suggested.
\end{abstract}

\section{Keywords}

Kinneret, Climate Change, Thermal Pollution, Heat Capacity, Precipitation Decline

\section{Introduction}

Water quality deterioration (pollution) in lakes is mostly considered through nutrient dynamics, particulate suspended solids and dissolved substances. Nutrient pollution trait is not restricted only to input enhancements. Nutrient pollution is quite often the outcome of water input reduction accompanied by their fluctuations resulting from diminished water exchange and a consequent elevation of nutrient availability. During the last 30 - 40 decades, the impact of fish's feeding habits was intensively included within the significances of lake pollution. Nevertheless, the study of climate change and Thermal pollution impact on aq- 
uatic ecosystems was less documented [1]. Thermal aspects were mostly aimed at the influence of power or nuclear Station effluents on the ambient fauna and flora. The study of the impact of natural and anthropogenic conditions on the quality and potential deterioration of Lake Kinneret waters has been widely explored and documented [2]. In these scientific documents, the role of thermal effect was poorly accessed. Consequently, climate change, (global warming) which was indicated recently, was not intensively considered. Also, awareness of the impact of anthropogenic constraints was not thoroughly considered. The present paper is an attempt to evaluate thermal fluctuations and their implications for water quality.

Heat capacity or thermal capacity is defined as the amount of heat energy that must be provided to an object (water mass) in order to raise its temperature by one unit.

Heat capacity is proportional to the water mass size. Heat capacity of a certain mass is divided by the weight or volume of the mass, yielding the specific heat capacity (or "specific heat"). The volumetric heat capacity value defines the heat capacity per volume as expressed in the following equations:

$$
\text { Specific Heat Capacity }=\mathrm{mc}
$$

where:

$\mathrm{C}=$ Specific Heat Capacity is given as: $\mathrm{cal} / \mathrm{kg} / \mathrm{T}: \mathrm{cal}=$ calories; $\mathrm{T}=$ temperature degree;

$$
\mathrm{C}=\mathrm{m} 4.186=\Delta \mathrm{Q} / \mathrm{m} \Delta \mathrm{T}
$$

We here:

$\mathrm{m}=$ mass; $4.186=$ water specific heat capacity

$$
\Delta \mathrm{Q}=\mathrm{Cm} \Delta \mathrm{T}
$$

$\Delta \mathrm{T}=$ Temperature increase

$\Delta \mathrm{Q}=$ Additional Heat amount (in calories)

where $\Delta \mathrm{Q}$ is the amount of heat that must be added to the water mass in order to raise its temperature from $\mathrm{T} 1$ to $\mathrm{T} 2$ by $1^{\circ} \mathrm{C}$ (Celsius).

The objective of this paper is enhancing awareness about global warm trend of climate change and its implication on freshwater ecosystem and the significance of minor signals.

\section{Material and Methods}

The lake water temperature data as measured at discrete depths, air temperature, and the Thermocline depths and Water Level (mbsl) in this paper are those collected in the central deepest sampling station (A) and were taken from the Lake Kinneret Data Base [3].

The Israeli Meteorological Service provided rainfall data collected in Dafna Station located in the Northern region of the Hula Valley (Kinneret Drainage Basin). The Plankton data was compiled from the Annual Reports [3] of the Kinneret Limnological Laboratory, IOLR. All data parameters were evaluated as 
periodical (annual and multi-annual) means of monthly averages. The analysis evaluated and given in this study is based on periodical characteristic measures of simple means. The time frame of 1969-2001 was divided into three periodical segments: 1969-1980; 1981-1990 and 1991-2001.

\section{Statistical Methods}

Statistical analyses used in this study were taken from STATA 9.1, Statistics-Data Analysis. The analyses used were: Simple linear predicted correlation and Fractional Polynomial (FP) predicted Regression and Simple Linear Regression (with $r^{2}$ and $p$, probability, values).

\section{Results}

Data provided in Table 1 indicates an obvious reduction of Bathymetric layer volumes (Serruya 1978: Chapter Bathymetry) and the increase of layer temperatures $(\Delta \mathrm{T})$ by $0.2^{\circ} \mathrm{C}-0.4^{\circ} \mathrm{C}$ between $1969-2001$.

Data provided in Table 2 indicates a decline of Bathymetric layers Heat Capacity ("Heat Budget", or "Heat Balance") between 1969 and 2001. The whole lake capacity was reduced from 16,016 to $11,985 \times 10^{6} \mathrm{Kcal}$ during 32 years. Moreover, a potential predictive decline is forecasted if the same thermal and

Table 1. Bathymetrical depth layer volumes $\left(10^{6} \mathrm{~m}^{3}\right)$ [4] and respective mean temperatures during the two periods: 1969-1980 (mean Water level-210.09 mbsl; mean lake volume $3834 \times 10^{6} \mathrm{~m}^{3}$ ) and 1991-2002 (mean Water Level $211.42 \mathrm{mbsl}$; mean lake volume $\left.286310^{6} \mathrm{~m}^{3}\right)$ and periodical $\Delta \mathrm{T}\left({ }^{\circ} \mathrm{C}\right)$.

\begin{tabular}{cccccc}
\hline $\begin{array}{c}\text { Depth } \\
\text { Layer }(\mathrm{m})\end{array}$ & $\begin{array}{c}\text { Volume }\left(10^{6} \mathrm{~m}^{3}\right) \\
1969-1980\end{array}$ & $\begin{array}{c}\text { Volume }\left(10^{6} \mathrm{~m}^{3}\right) \\
1991-2002\end{array}$ & $\begin{array}{c}\text { Mean Temp. }\left({ }^{\circ} \mathrm{C}\right) \\
(1969-1980)\end{array}$ & $\begin{array}{c}\text { Mean Temp. }\left({ }^{\circ} \mathrm{C}\right) \\
(1991-2002)\end{array}$ & $\begin{array}{c}\Delta \mathrm{T} \\
\left({ }^{\circ} \mathrm{C}\right)\end{array}$ \\
\hline $0-10$ & 1573 & 1279 & 21.9 & 22.3 & 0.4 \\
$11-20$ & 1215 & 992 & 20.2 & 20.4 & 0.2 \\
$21-30$ & 729 & 506 & 16.3 & 16.7 & 0.4 \\
$31-40$ & 309 & 85 & 15.3 & 15.5 & 0.2 \\
\hline
\end{tabular}

Table 2. Calculated values of standing stock and additional change $(\Delta \mathrm{Q})$ of Heat Capacity (C) in two periods: 1969-1980 and 1991-2001 with respect to depth layers (for $\Delta \mathrm{T}$, see Table 1).

\begin{tabular}{ccccc}
\hline $\begin{array}{c}\text { Depth } \\
\text { Layer }(\mathrm{m})\end{array}$ & $\begin{array}{c}\mathrm{C}=\text { Heat Capacity } \\
\left(10^{6} \mathrm{Kcal}\right)\end{array}$ & $\begin{array}{c}\mathrm{C}=\text { Heat Capacity } \\
\left(10^{6} \mathrm{Kcal}\right)\end{array}$ & $\begin{array}{c}\Delta \mathrm{Q}=\mathrm{C} \times \Delta \mathrm{T} \\
\left(10^{6} \mathrm{Kcal}\right)\end{array}$ & $\begin{array}{c}\text { Potential } \Delta \mathrm{Q}^{\circledR} \\
\mathrm{Q}=\mathrm{C} \times \Delta \mathrm{T} \\
\left(10^{6} \mathrm{Kcal}\right)\end{array}$ \\
\hline $0-10$ & 6585 & 5354 & 2634 & 2142 \\
$11-20$ & 5086 & 4153 & 1017 & 831 \\
$21-30$ & 3052 & 2118 & 1221 & 847 \\
$31-40$ & 1293 & 360 & 259 & 72 \\
Total & 16,016 & 11,985 & 5131 & 3892 \\
\hline
\end{tabular}

$@$ = Same volumes of depth layers and similar $\Delta \mathrm{T}$ (see Table 1) values as for the interval of 1969-2001, i.e. later onwards $\Delta \mathrm{Q}$ was calculated based on 1969-2001 results using similar $\Delta \mathrm{T}$. 
Bathymetric conditions continue. A case of confusion is presented in Table 2. Water temperature increased between 1969 and 2001 accompanied by a decline of heat capacity. What could be the ecological significance of such a case? During a continuation of the heating process (global warming), a decline of heat capacity demand for temperature elevation is predicted. In other words, Equal Heat investment under low and high water level will result in a dissimilar water temperature.

Data shown in Figure 3 indicates how Bathymetrical and Thermal condition changes are related to Water Level (WL) fluctuations: When WL declined from $210.09 \mathrm{mbsl}$ to $211.42 \mathrm{mbsl}$, the total volume of the Bathymetric layer declined from 3826 to $2863 \times 10^{6} \mathrm{~m}^{3}$ and the Heat Capacity declined from 16,016 to $11,985 \times 10^{6} \mathrm{Kcal}$.

The data provided in Table 3 are pertinent to Plankton (Phyto. and Zoo.) changes during 1969-2001: Prominent enhancement of Phytoplankton and decline of Zooplankton biomasses. Most of the previous Kinneret phytoplankton studies that were aimed at its exposure and reverse response to environmental conditions (nutrient, grazing, light, temperature, water mass motion, etc.) impact utilized measures of aerial or volumetric concentrations. Exceptional accessibility is presented through the comprehensive model constructions when algal loads are evaluated. The quantitative relations within the ecosystem structure in this paper are due not only to biotic compartments but also to the thermal component (heat capacity). It, therefore, indicates that rising water temperature is not accompanied by the enhancement of Heat Capacity resulting from a reduction of water mass.

The data provided in Table 4 indicates the closely related changes in rain decline and air temperature increase.

Table 3. Periodical Means of Plankton groups Biomass $\left(\mathrm{g} / \mathrm{m}^{2}\right)$ : Total Phyto and Total Zoop; Peridinium, Chlorophyta, Diatoms, Cyanobacteria, Rotifera, Cladocera, and Copepoda. The changes between 1996-1980 and 1991-2001 are given in percentage: $\mathrm{E}=\mathrm{En}$ hancement, $\mathrm{D}=$ Decline.

\begin{tabular}{ccccc}
\hline Planktonic Parameter & $1969-1980$ & $1981-1990$ & $1991-2001$ & $\begin{array}{c}\text { \% Change, } \\
\mathrm{D}=\text { Decline, E = Enhancement }\end{array}$ \\
\hline Total Phytoplankton & 60.6 & 81.6 & 87.1 & $44 \mathrm{E}$ \\
Peridinium & 49.8 & 55.4 & 50.3 & $1 \mathrm{E}$ \\
Chlorophyta & 6.2 & 13.4 & 15.5 & $150 \mathrm{E}$ \\
Diatoms & 2.4 & 9.7 & 14.6 & $508 \mathrm{E}$ \\
Cyanobacteria & 2.2 & 3.1 & 6.7 & $205 \mathrm{E}$ \\
Total Zooplankton & 32.3 & 21.4 & 25.2 & $22 \mathrm{D}$ \\
Rotifera & 2.4 & 1.6 & 1.9 & $21 \mathrm{D}$ \\
Cladocera & 18.2 & 13 & 16 & $12 \mathrm{D}$ \\
Copepoda & 11.7 & 6.8 & 7.3 & $38 \mathrm{D}$ \\
\hline
\end{tabular}


Table 4. Periodical means of annual precipitations $(\mathrm{mm})$, daily maximal and minimal air temperatures (Dafna Station).

\begin{tabular}{cccc}
\hline Period & $\begin{array}{c}\text { Annual Precipitation } \\
(\mathrm{mm})\end{array}$ & $\begin{array}{c}\text { Daily Minimal Air } \\
\text { Temperature }\left({ }^{\circ} \mathrm{C}\right)\end{array}$ & $\begin{array}{c}\text { Daily Maximal Air } \\
\text { Temperature }\left({ }^{\circ} \mathrm{C}\right)\end{array}$ \\
\hline $1969-1980$ & 657 & 12.6 & 25.6 \\
$1981-1990$ & 617 & 11.8 & 25.0 \\
$1991-2001$ & 604 & 12.8 & 26.0 \\
\hline
\end{tabular}

The closely related dynamics of rain, air temperature and lake water level are shown in Table 5. Calculated Linear Regression (LR) between Surface Water and Air Temperatures resulted to $r^{2}=0.5630$ and $p=0.0008$ (i.e. significant), while similar LR analysis between Surface Temperature and Water Level indicated Not Significant relations. Therefore, the evaluation of those parameter relations desires increasing flexibility as afforded by the conventional polynomial model, the Fractional Polynomial Regression.

The data provided in Figure 1 indicates that during 1987-1994 Air and Surface Temperatures were closely related while during 1995-2001 and in 1986 air temperature was lower by approximately $2^{\circ} \mathrm{C}$, indicating climate change development (global warming) aimed at the atmospheric air warming process. Nevertheless, early (1969-1980) Bathymetrical heat transfer was very close to the later period of 1991-2001 (Figure 2). Therefore, it is needed to discriminate heat transfer deeper from surface to bottom and through the air-surface interface. Figure 3 indicates no thermal difference between air and surface within the range of $0.5^{\circ} \mathrm{C}-1.5^{\circ} \mathrm{C}$, while when the range is expanded above $23^{\circ} \mathrm{C}$ at the surface, $2.5^{\circ} \mathrm{C}$ of the surface is related to $3.5^{\circ} \mathrm{C}$ of air temperature, i.e. heat transfer slows down slightly (Figure 3). Similarity is evaluated when the Fractional Polynomial Regression between Surface Temperature and Water Level: Within the WL range of $209-211 \mathrm{mbsl}$, only $0.5^{\circ} \mathrm{C}$ is due to surface temperature change while lower WL ( $211-214 \mathrm{mbsl})$ corresponds to a change of about $1.6^{\circ} \mathrm{C}$ of surface temperature (Figure 4). WL changes between 209 and 211 correspond to air temperature decline of approximately $1^{\circ} \mathrm{C}$ while WL decline $(211-214 \mathrm{mbsl})$ was followed by an air temperature increase of about $2^{\circ} \mathrm{C}$ (Figure 5). Figure 6 and Figure 7 represent a compatible situation: decline of WL and surface water during 1986-1993, and both were elevated onwards: WL from 210 to $213.5 \mathrm{mbsl}$ and surface water temperature from $23.7^{\circ} \mathrm{C}$ to $24.3^{\circ} \mathrm{C}$. In other words, from the mid-1990's and onwards, climate change of warming and precipitation decline (lower WL) is indicated.

\section{Thermocline Depth, Water Temperature, Water Level and Temporal Changes}

The Bathymetrical and thermal fluctuations of the Thermocline as related to Water Level change indicate the following. WL was roughly stable from 1969 through the mid-1980s and later dropped by approximately 2 meters (Figure 8). 


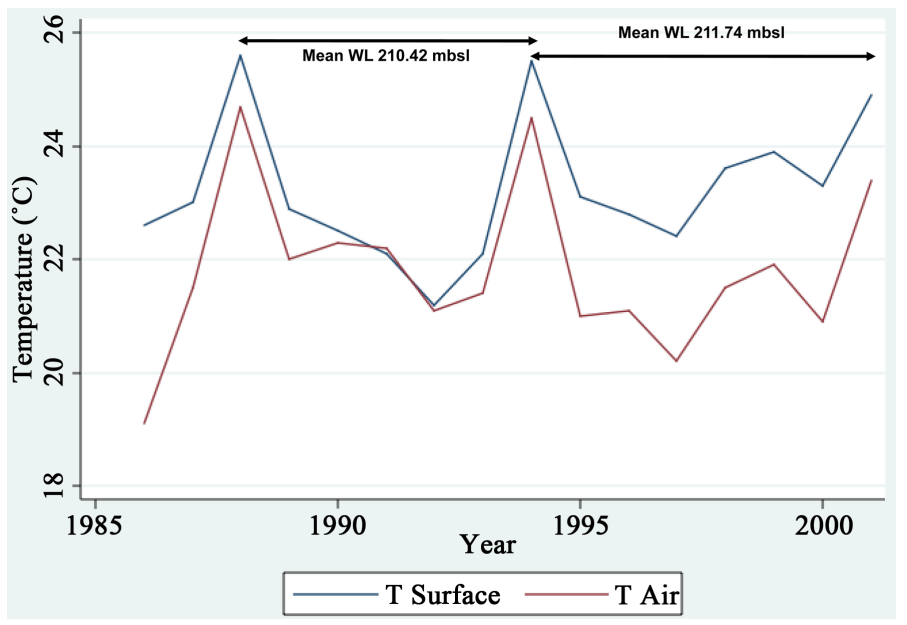

Figure 1. Annual (1986-2001) means of water surface (T Surface) and Air (T Air) Temperatures $\left({ }^{\circ} \mathrm{C}\right)$.

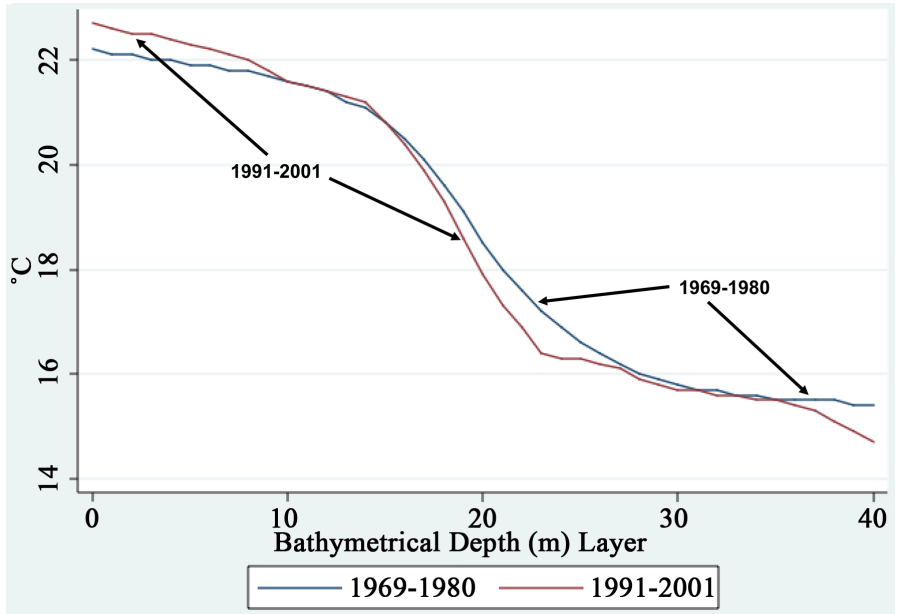

Figure 2. Periodical (1969-1980; 1991-2001) mean water temperature $\left({ }^{\circ} \mathrm{C}\right)$ of bathymetrical depth $(\mathrm{m})$ layers.

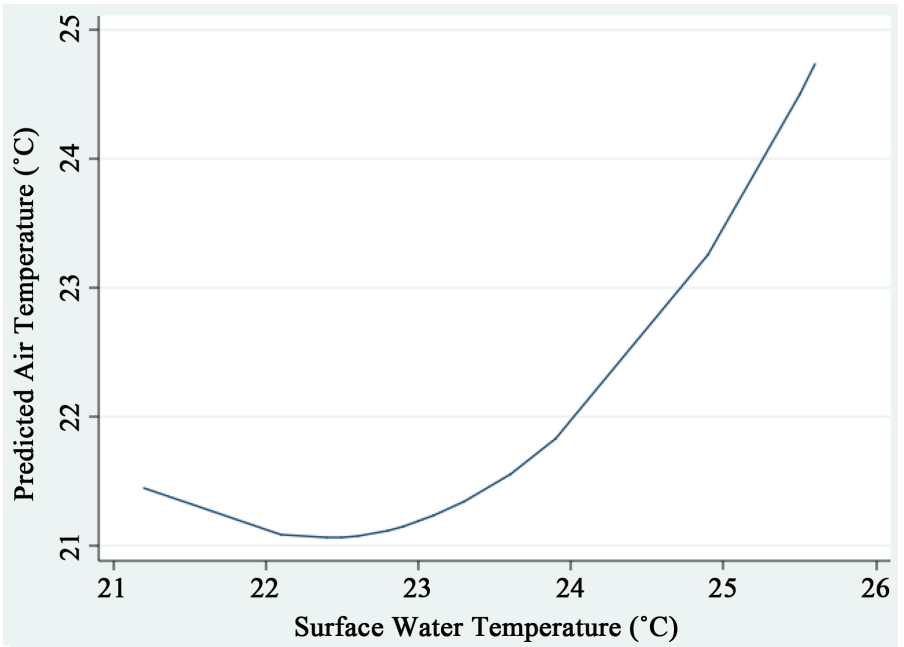

Figure 3. Fractional polynomial regression between annual (1986-2001) mean temperatures $\left({ }^{\circ} \mathrm{C}\right)$ of surface (T surface) and air (T Air). 


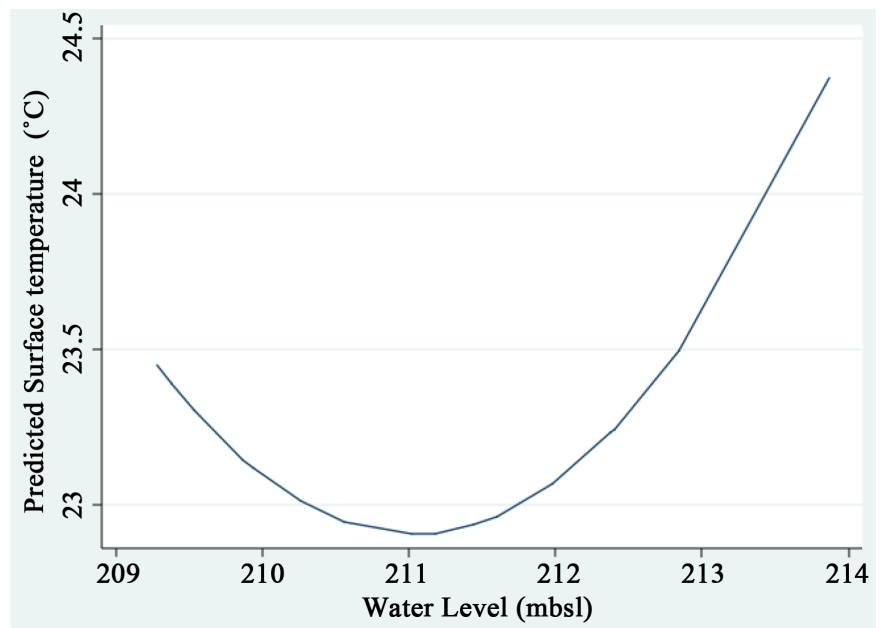

Figure 4. Fractional polynomial regression between annual (1986-2001) mean temperatures $\left({ }^{\circ} \mathrm{C}\right)$ of surface (T surface) and Water Level (mbsl).

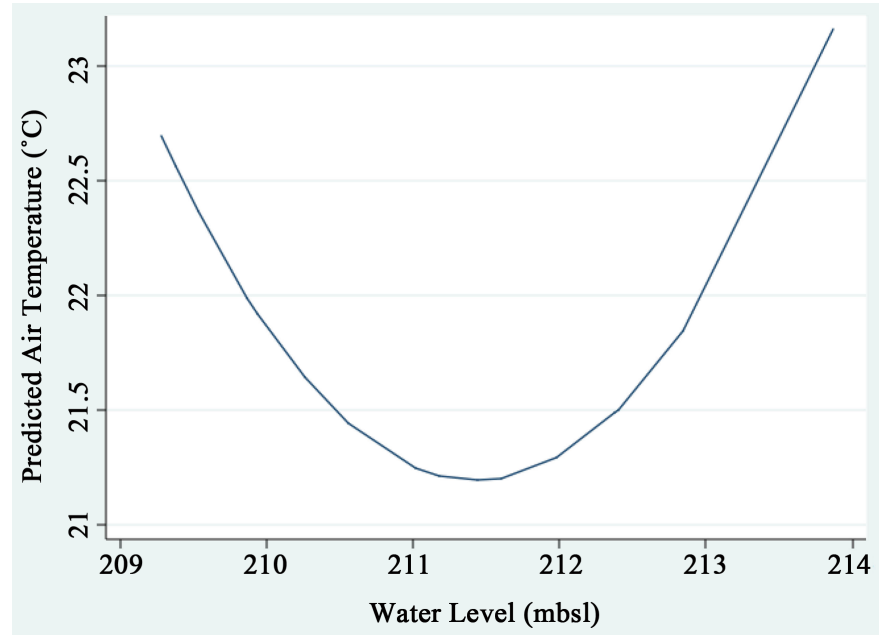

Figure 5. Fractional polynomial regression between water level and air temperature during 1986-2001.

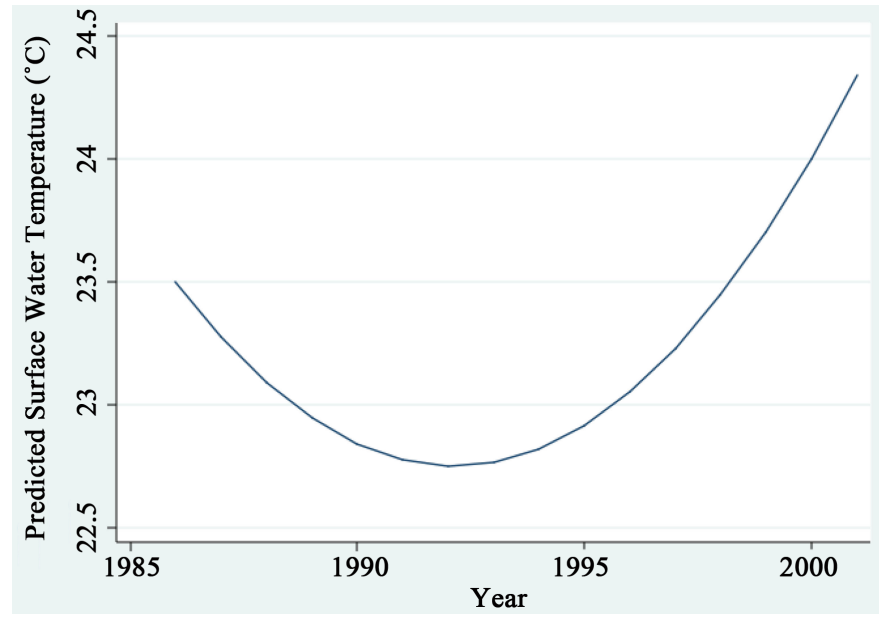

Figure 6. Fractional polynomial regression of temporal changes of annual means of surface water temperature $\left({ }^{\circ} \mathrm{C}\right)$ during 1986-2001. 


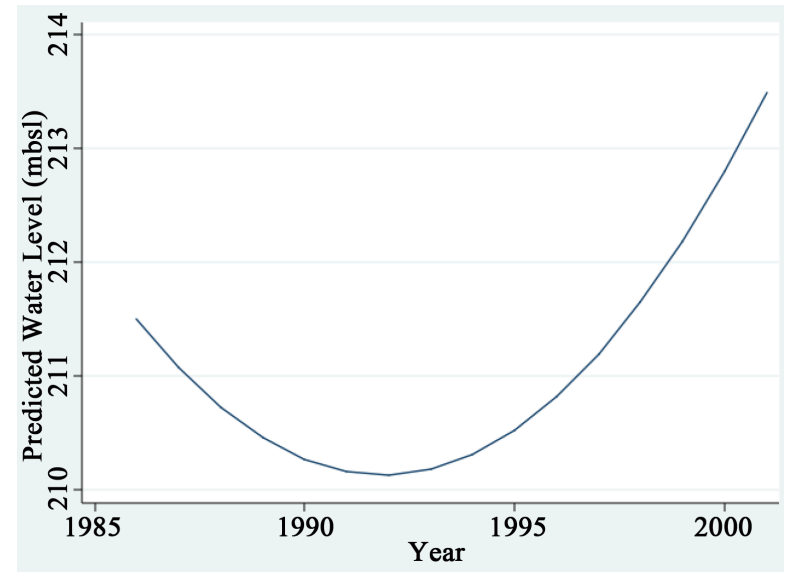

Figure 7. Fractional polynomial regression between annual means of water level and years during 1986-2001.

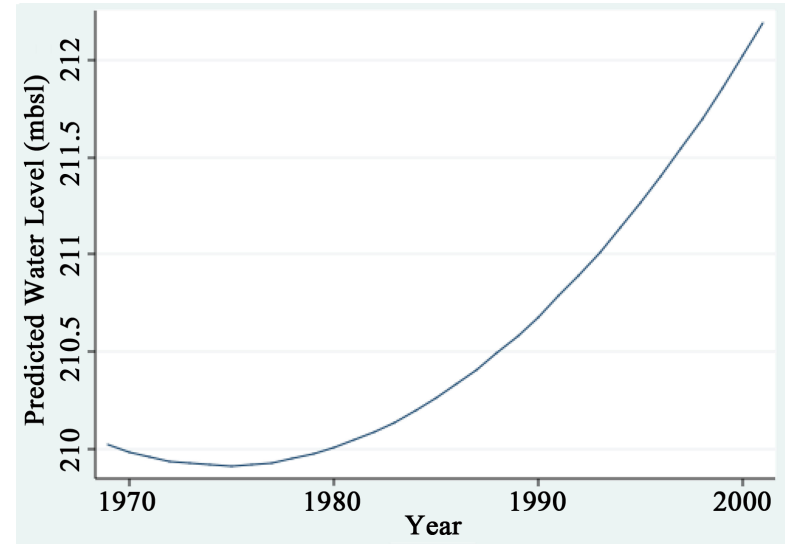

Figure 8. Fractional polynomial regression between annual means of water level (mbsl) and years during 1969-2001.

Table 5. Annual means of Lake Kinneret Water Level, air temperatures of three meters above water surface and surface water.

\begin{tabular}{cccc}
\hline Year & Surface $\left({ }^{\circ} \mathrm{C}\right)$ & Air $\left({ }^{\circ} \mathrm{C}\right)$ & WL $(\mathrm{mbsl})$ \\
\hline 1986 & 22.6 & 19.1 & 211.60 \\
1987 & 23 & 21.5 & 219.26 \\
1988 & 25.6 & 24.7 & 209.53 \\
1989 & 22.9 & 22 & 211.02 \\
1990 & 22.5 & 22.3 & 211.98 \\
1991 & 22.1 & 22.2 & 212.40 \\
1992 & 21.2 & 21.1 & 209.38 \\
1993 & 22.1 & 21.4 & 209.28 \\
1994 & 25.5 & 24.5 & 209.94 \\
1995 & 23.1 & 21 & 209.87 \\
1996 & 22.8 & 21.1 & 210.56 \\
1997 & 22.4 & 20.2 & 211.18 \\
1998 & 23.6 & 21.5 & 211.44 \\
1999 & 23.9 & 21.9 & 212.38 \\
2000 & 23.3 & 20.9 & 212.84 \\
2001 & 24.9 & 23.4 & 213.87 \\
\hline
\end{tabular}


The depth of the Thermocline was approximately stable when WL was above $211 \mathrm{mbsl}$. The Thermocline dropped by approximately eight meters when WL subsidence was below $211 \mathrm{mbsl}$ (Figure 9). The temporal changes of the Thermocline depth indicate a shallower measure until the mid-1980's by about 4 meters, which later on became deeper by 8 meters (Figure 10). Thermocline temperature change with relation to depth allocation indicates an increase of $1^{\circ} \mathrm{C}$ along 8 meters deepening and $2^{\circ} \mathrm{C}$ elevation below $23 \mathrm{~m}$ depth allocation (Figure 11).

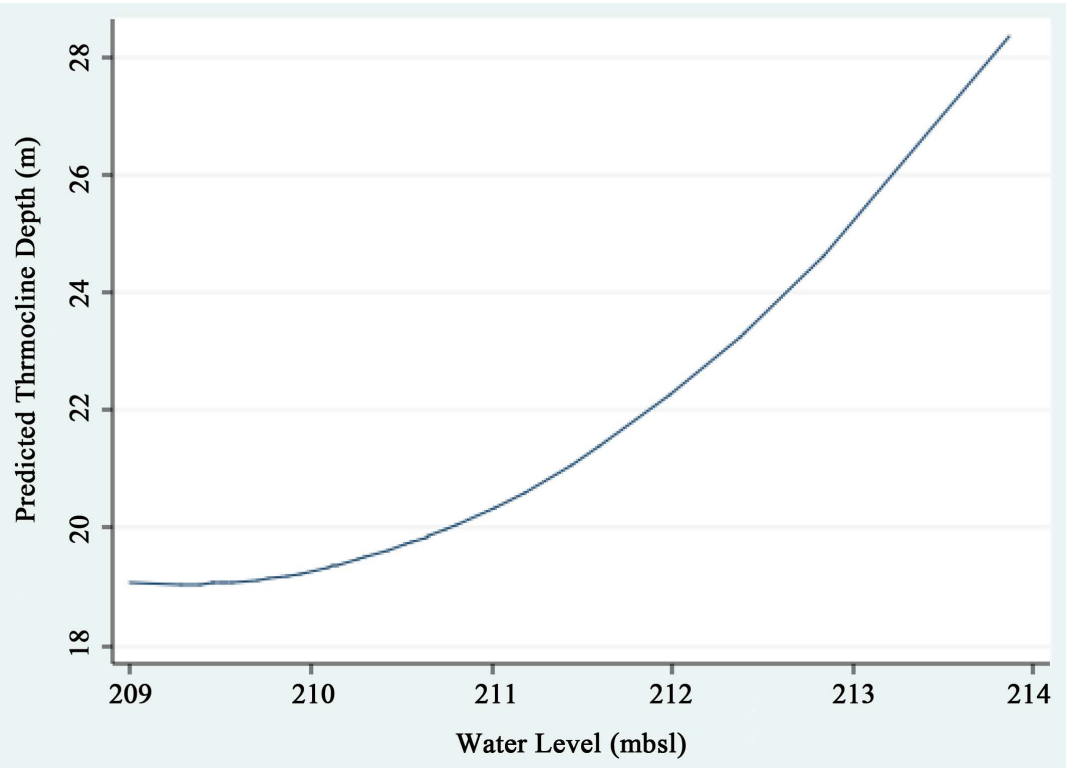

Figure 9. Fractional Polynomial Regression between annual means of Water Level (mbsl) and Thermocline Depth (m) during 1986-2001.

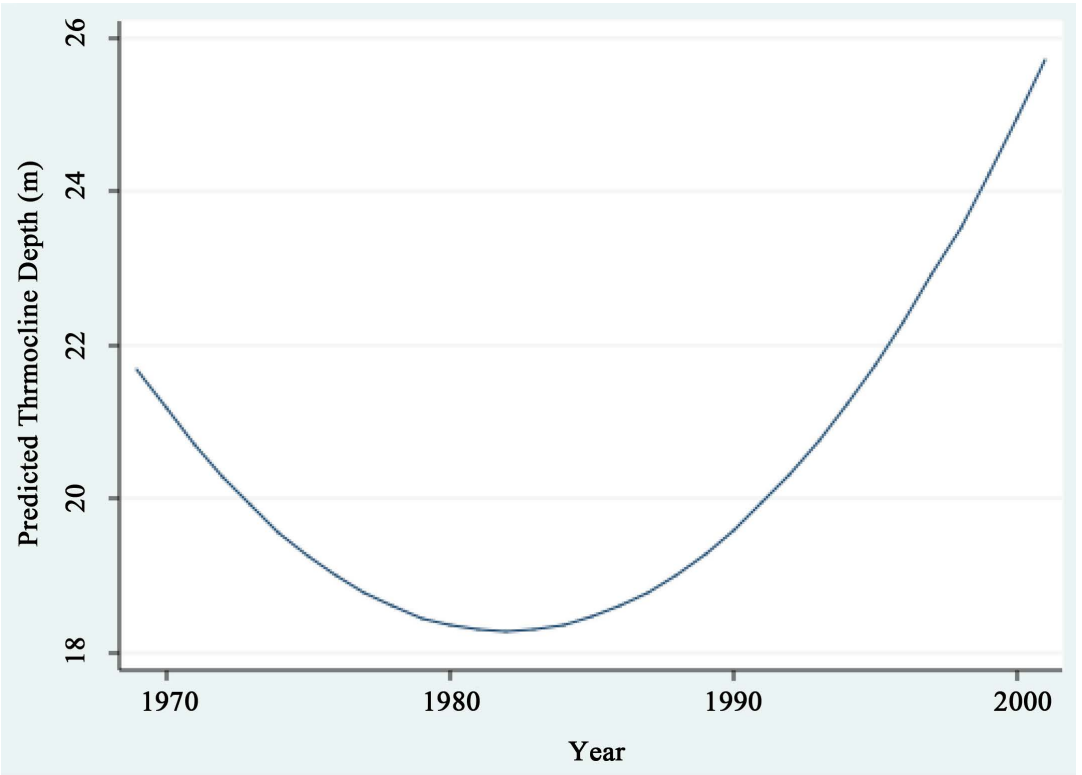

Figure 10. Fractional Polynomial Regression between annual means of Years and Thermocline Depth (m) during 1969-2001. 


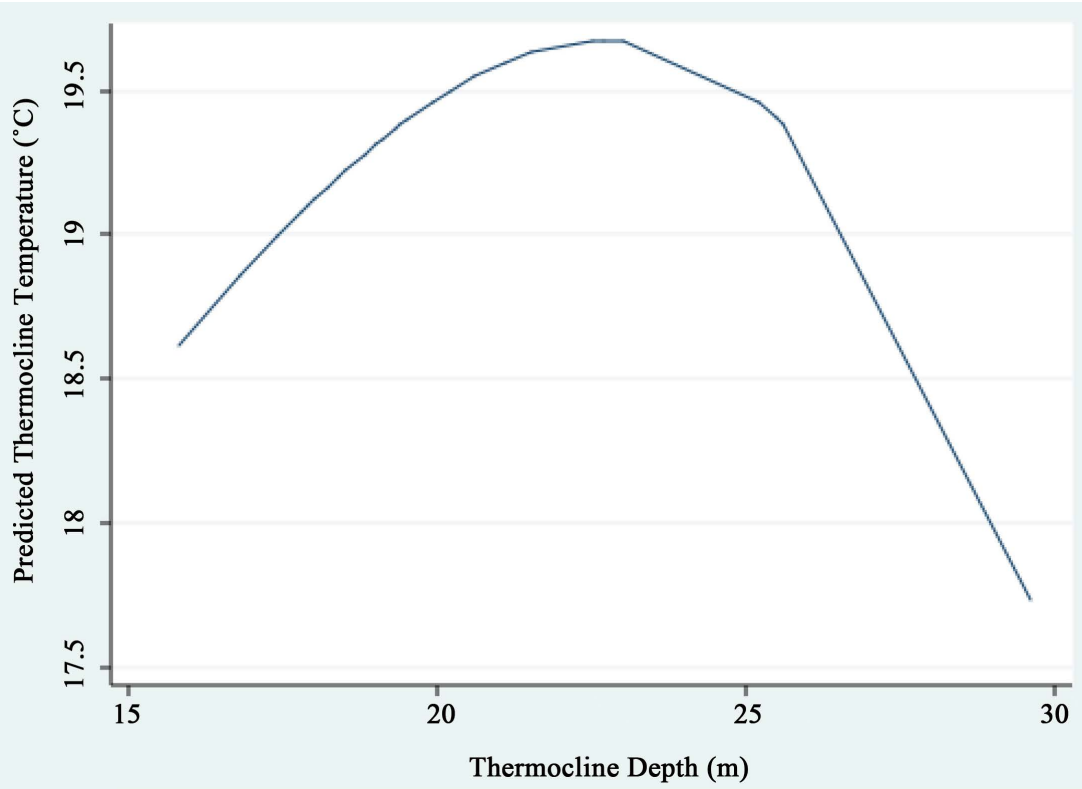

Figure 11. Fractional Polynomial Regression between Annual means of Thermocline Depth $(\mathrm{m})$ and Temperature $\left({ }^{\circ} \mathrm{C}\right)$ during 1986-2001.

\section{Discussion}

In previous studies on the thermal structural and temporal changes in Lake Kinneret the significance of heat capacity and its relevance to ecological features ware not widely considered. Changes in air temperature and Rainfall normally have a direct impact on lake characteristics [1] [5] [6]. Shifts in precipitation cause changes in water budget and hydraulic residence time as well as in water level, and consequently in total volume and Thermocline depth, resulting in Bathymetrical layer volumes and heat capacity differences. Air temperature elevation causes warmer lake surface waters which, in turn, increase stratification stability due to profoundly increased water density gradient. Reduction in bottom-up fluxed nutrient migration is possibly enhanced. A decline of rainfall could be the reason for longer residence time followed by nutrient accumulation, a well-known cause of pollution and water quality deterioration. Moreover, bloom-forming Cyanobacteria are likely to be favored in a warming climate [7] [8] [9] [10]. It was reported that in the last century temperature increased by approximately $0.7^{\circ} \mathrm{C}$ and is likely to be elevated by $1^{\circ} \mathrm{C}-6^{\circ} \mathrm{C}$ by the end of the 21 st century. The IPCC (2007) report is about increasing temperature of lake and stream surface waters, increasing of Hypolimnetic temperatures in deep lakes, enhancement of nutrients and particulate matter downstream to lakes, changes in the water level of lakes and elevation of lake salinity. Moreover, higher water temperature leads to enhancement of Primary and Secondary Productions and algal bloom intensities, potential DO depletion and several other changes in the food-web structure [8] [11] [12] [13]. The impact of temperature changes on the ecophysiological habits of zooplankton (reproduction, feeding, respiration, feeding efficiency, egg development time, etc.) in Lake Kinneret was 
widely studied [14] [15] [16] [17]. It was documented that temperature elevation enhances metabolic activity accompanied by biomass density decline as a result of a higher loss of food energy (lower feeding efficiency). The environmental significance is the decline of biomass density when the temperature is increasing, while fish predation is enhanced simultaneously.

Apparent data provided in Table 2 and Table 6 indicates a paradoxical situation: water temperature is increasing while Heat Capacity declined during 1969-2001. The heat dynamical feature resulted from thermal pollution deterioration of water quality: Climate change expressed as dryness trend (rainfall reduction) resulted in a shrinking of water volume and although water temperature increased Heat capacity declined. Conclusively, the warming trend of air temperature induces water heating beside volume reduction, resulting in a decline of heat capacity. It is likely that, for the realistic estimation of the influence of global warming on lake ecosystem, a combined measure of the temperature and natural volume of water is required. The data provided in Table 3 shows prominent increase of the non-Pyrrhophyte algal biomass density and decline of large body zooplankton (Copepoda, Cladocera) during 1969-2001. These are the major consequences of thermal pollution in Lake Kinneret. Nevertheless, it cannot be completed without introducing the impact of Nutrient availability. Climate change (rainfall decline) induced the lowering of external nutrient inputs (mostly Nitrogen) while internal factors of volume shrinkage and possibly internal conditions enhanced Phosphorus release from the sediments. Conclusively, the thermal pollution-driven eco-forces enforced a combination between the external (climate condition) and internal conditions (enhanced $\mathrm{P}$ release from the sediments) to enhance water quality deterioration.

Thermal pollution is defined in Limnological literature as a prominent factor that facilitates water quality deterioration. Cases of such traits are, among others,

Table 6. Periodical average changes of Layer Depth Volumes, Mean Temperatures and Heat Capacities. Periods: $1=1969-1980 ; \mathrm{WL}=210.09$ mbsl; $2=1981-1990 ; \mathrm{WL}=210.51$ mbsl; 3 = 1991-2002; WL= 211.42 mbsl; $\mathrm{V}=$ Depth Layer Volume $\left(10^{6} \mathrm{~m}^{3}\right) ; \mathrm{T}=$ Layer Mean Temperature $\left({ }^{\circ} \mathrm{C}\right)$; C = Layer Heat Capacity $(\mathrm{C})\left(10^{6} \mathrm{Kcal}\right)$.

\begin{tabular}{ccccccc}
\hline Period & Depth Layer Parameter & $0-10$ & $11-20$ & $21-30$ & $31-40$ & Total \\
\hline 1 & $\mathrm{~V}\left(10^{6} \mathrm{~m}^{3}\right)$ & 1573 & 1215 & 729 & 309 & 3826 \\
1 & $\mathrm{~T}\left({ }^{\circ} \mathrm{C}\right)$ & 21.9 & 20.2 & 16.3 & 15.3 & \\
1 & $\mathrm{C}\left(10^{6} \mathrm{Kcal}\right)$ & 6585 & 5086 & 3052 & 1293 & 16016 \\
2 & $\mathrm{~V}\left(10^{6} \mathrm{~m}^{3}\right)$ & 1502 & 1144 & 658 & 167 & 3471 \\
2 & $\mathrm{~T}\left({ }^{\circ} \mathrm{C}\right)$ & 22.1 & 20.0 & 15.8 & 14.9 & \\
2 & $\mathrm{C}\left(10^{6} \mathrm{Kcal}\right)$ & 6287 & 4789 & 2754 & 699 & 14529 \\
3 & $\mathrm{~V}\left(10^{6} \mathrm{~m}{ }^{3}\right)$ & 1279 & 992 & 506 & 86 & 2863 \\
3 & $\mathrm{~T}\left({ }^{\circ} \mathrm{C}\right)$ & 22.3 & 20.4 & 16.7 & 15.5 & \\
3 & $\mathrm{C}\left(10^{6} \mathrm{Kcal}\right)$ & 5354 & 4153 & 2118 & 360 & 11985 \\
\hline
\end{tabular}


due to power plant coolant effluents or soil erosion by deforestation enhancing exposure to sunlight. The potential damages to the aquatic ecosystem are decreasing DO concentration, enhanced Oxygen depletion, and increasing metabolic rates of aquatic organisms at the entire trophic levels structure. Metabolic activity enhancement is due to the increasing level of enzyme activity. The comprehensive pattern of energy flow through the food web compartments is accelerated. The decline of the biodiversity within the ecosystem, accompanied by the enhancement of algal (Greens and Diatoms are replaced by Cyanobacteria) Primary Production and bloom formation, is predicted. Consequently, the global situation of water scarcity and the intensive demands for food production allocate thermal pollution based on the priority of human concerns. The presented case of thermal pollution in Lake Kinneret is a long-term process differing from abrupt phenomena such as industrial effluents of which thermal shocks are inhibited. It was recently predicted that an increase in global temperatures of about $1^{\circ} \mathrm{C}-6^{\circ} \mathrm{C}$ by the end of the 21 st century is predicted [8].

Three physical parameters of thermal water characteristics are considered: Temperature, Heat Capacity and Thermal conductivity. Thermal conductivity of air is 23.4 times lower than that of water. Therefore, atmospheric air heating is slower than heat transfer between Bathymetrical water layers, causing surface water to be warmer than the air temperature. The present study considers the long term of multi-annual periodical fluctuations. When water temperature declines, heat conductance and Capacity decline as well. Nevertheless, Heat capacity is respectively related to the mass size (volume of water); therefore, precipitation reduction followed by WL measure is significantly integrated. Climate Change expression in Lake Kinneret and its Watershed was air and water temperature elevation accompanied by precipitation decline. River discharges declined and lake WL dropped. Temperature increase, together with water volume shrinkage and reduced heat capacity, created a stronger steepness of the thermal gradient, which respectively enhanced conductance. The onwards development was simultaneous heating of the Kinneret water column and acceleration of biological activity, resulting in a trend of water quality deterioration. Appropriate management under those circumferences is shortening of water residence time by enhancement of exchange. Figures 1-3 indicate a higher temperature of the uppermost 0 - $11 \mathrm{~m}$ layer under lower WL. On the contrary, in deep layers during high WL periods, the temperature was lower (Figure 2). Figure 3 indicates a positive relationship between the temperature of the air and surface waters when the air temperature is higher than $21.5^{\circ} \mathrm{C}$ and surface temperature is $>23.5$. Consequently, it is suggested that surface water is affected by air heating and probably Heat Conductance from deeper layers is significant. Figure 4 indicates that surface water heat fluctuates very little $\left( \pm 0.5^{\circ} \mathrm{C}\right)$ under high WL $(>211$ mbsl). Under low WL $(<211 \mathrm{mbsl})$ the temperature of surface water increases with WL decline (211 - $214 \mathrm{mbsl}$ ). Conclusively, the thermal impact is related to air warming, precipitation decline and water warming. 


\section{Conclusive Remarks}

Surface water heat fluctuates very little $\left( \pm 0.5^{\circ} \mathrm{C}\right)$ under high WL $(>211 \mathrm{mbsl})$. Under low WL $(<211 \mathrm{mbsl})$, the temperature of surface water increases with WL decline (211 - $214 \mathrm{mbsl}$ ). The temperature of deeper layers during high WL decreased. A direct positive relationship between the temperature of the air and surface waters was indicated when the air temperature was higher than $21.5^{\circ} \mathrm{C}$ with a surface temperature $>23.5$. Consequently, it is suggested that surface water is affected by air heating and partly also by upward Heat Conductivity from deeper layers. Conclusively, the thermal impact is related to air warming, precipitation decline and water warming. Because the outcome of warming lake water is an enhancement of the metabolic activity of the lake biota, the appropriate management design is shortening of water residence time by enhancement of water exchange. This study exemplifies that even minor thermal fluctuations might be a signal of ecological modification. The only thermal measure of degrees might be insignificance for a lake under water input reduction accompanied by WL and volume decline.

\section{Conflicts of Interest}

The authors declare no conflicts of interest regarding the publication of this paper.

\section{References}

[1] Walther, G.R., Post, E., Menzel, P., Parmesan, A., Beebee, C., Fromentin, T., Hoegh-Guldberg, O., Bairlein, F., et al. (2002) Ecological Responses to Recent Climate Change. Nature, 416, 389-395. https://doi.org/10.1038/416389a

[2] Gophen, M. (2018) Ecological Research in the Lake Kinneret and Hula Valley (Israel) Ecosystems. Scientific Research Publishing Inc., Wuhan’, 336 p.

[3] LKDB (1969-2001) Annual Reports. Kinneret Limnological Laboratory IOLR.

[4] Serruya, C. (1978) Chapter I: General Background, D: Bathymetry. In: Seruya, C., Ed., Lake Kinneret, Monographyae Biologicae, Dr. W. Junk, BV Publisher, The Hague, 125-131.

[5] Woodward, G., Perkins, D.M. and Brown, L.E. (2010) Climate Change and Freshwater Ecosystems: Impacts across Multiple Levels of Organization. Philosophical Transactions of the Royal Society B, 365, 2093-2106. https://doi.org/10.1098/rstb.2010.0055

[6] McKnight, D., Brakke, D.F. and Mulholland, P.J. (1996) Freshwater Ecosystems and Climate Change in North America. Limnology and Oceanography, 41, 815-1149.

[7] Vincent, W.F. (2010) Chapter: Effects of Climate Change in Lakes. In: Likens, G.E., Ed., Lake Ecosystem Ecology: A Global Perspective: A Derivative of Encyclopedia of Inland Waters, Academic Press, |Cambridge, MA, 65-70.

[8] IPCC (2007) Fourth Assessment Report: Synthesis Report AR4 Climate Change: Synthesis Report. Working Group Report: The physical Science Basis, 989-996.

[9] Mackay, A.W., Ryves, D.B., Morley, D.W., Jewson, D.H. and Rioual, P. (2006) Assessing the Vulnerability of Endemic Diatom Species in Lake Baikal to Predicted Future Climate Change: A Multivariate Approach. Global Change Biology, 12, 
2297-2315. https://doi.org/10.1111/j.1365-2486.2006.01270.x

[10] Wiender, C., Rücker, J., Brüggemann, R. and Nixdorf, B. (2007) Climate Change Affects Timing and Size of Population of an Invasive Cyanobacterium in Temperate Regions. Oecologia, 152, 473-484. https://doi.org/10.1007/s00442-007-0683-5

[11] Sweeney, B.W., Jackson, J.K., Newbold, J.D. and Funk, D.H. (1992) Climate Change and the Life Histories and Biogeography of Aquatic Insects in Eastern North America. In: Firth, P. and Fisher, S.G., Eds., Global Climate Change and Freshwater Ecosystems, Springer, New York, 143-170.

https://doi.org/10.1007/978-1-4612-2814-1_7

[12] Brooks, A.S. and Zastrow, J.C. (2002) Potential Influence of Climate Change on Offshore Primary Production in Lake Michigan. Journal of Great Lakes Research, 28, 597-607. https://doi.org/10.1016/S0380-1330(02)70608-4

[13] O’Reilly, C.M., Alin, S.R., Plisnier, P.D., Cohen, A.S. and Mckee, B.A. (2003) Climate Change Decreases Aquatic Ecosystem Productivity of Lake Tanganyika, Africa. Nature, 424, 766-768. https://doi.org/10.1038/nature01833

[14] Gophen, M. (2013) The Impact of Temperature Elevation on the Decline of Cyclopoid Population in Lake Kinneret (Israel). The Journal of Ecology-Photon Journal, 107, 230-239.

[15] Gophen, M. (2015) Thermal Preference by Mesocyclops ogunnus (Onabamiro, 1957). Open Journal of Ecology, 5, 15-21. https://doi.org/10.4236/oje.2015.52002

[16] Gophen, M. (2015) Ecophysiology of Lake Kinneret (Israel) Zooplankton. Open Journal of Ecology, 5, 187-198. https://doi.org/10.4236/oje.2015.55016

[17] Gophen, M., and Azoulay, B. (2002) The Trophic Status of Zooplankton Communities in Lake Kinneret (Israel). Internationale Vereinigung für Theoretische und Angewandte Limnologie: Verhandlungen, 28, 836-839.

https://doi.org/10.1080/03680770.2001.11901831 